\title{
Heterogeneity in chronic disease outcomes among women and men in midlife: examining the role of stability and change in childhood economic hardship
}

\author{
Cole Etherington \\ netherin@uwo.ca \\ Andrea Willson \\ Kim Shuey \\ Western University, Canada \\ Western University, Canada \\ Western University, Canada
}

(Received April 2015 Revised September 2015) 
of disease and health over the life course.

Through its emphasis on human development and aging as lifelong processes (Elder, Johnson, \& Crosnoe, 2003), the life course perspective has directed attention to the 'long arm' of childhood disadvantage, or how early life conditions impact health and other outcomes in adulthood. Research increasingly has recognised the importance of childhood origins in shaping health disparities (Diprete \& Eirich, 2006; Murray et al., 2011), yet little work has examined how childhood context may differentially affect men and women. Existing research treats gender as a control variable rather than a focal point (e.g. Bowen, 2010), often attempting to 'explain away' gender differences rather than examining how social factors may operate differently for women and men and lead to divergent health trajectories and heterogeneity within groups (Evans-Campbell, Lincoln \& Takeuchi, 2010). Further, childhood disadvantage has been treated as static, rather than as a dynamic process involving stability and change over time (e.g. Lemelin et al., 2009; Pudrovska \& Anikputa, 2013; Walsemann, Ailshire, Bell \& Frongillo, 2012), and its effects rarely compared across health outcomes.

The current study advances research on childhood disadvantage, gender, and health by conceptualising and measuring childhood economic context as a dynamic process that may affect disease onset in midlife differently for women and men. Specifically, we take into consideration stability and change in the experience of childhood poverty and its impact on health in midlife. Using the US Panel Study of Income Dynamics (PSID), these relationships are examined across four chronic disease outcomes that are among the most prominent causes of morbidity and mortality in the United States.

\section{Background}

Diabetes, hypertension, arthritis, stroke, heart attack and heart disease are among the most common causes of morbidity and mortality in the US (Centers for Disease Control and Prevention, 2014; Gluckman \& Hanson, 2005; Heron 2007). In general, men tend to experience more life-threatening chronic diseases at younger ages, while women have higher rates of chronic debilitating conditions (Bird \& Rieker,
2008). Across all age groups, heart disease is more prevalent among men than women, although it remains the leading cause of death for both genders (National Center for Health Statistics, 2009). Partly due to heart attack occurring at later ages for women, nearly half of all fatal heart attacks each year in the US occur in women. For men up to age 75 , the incidence of stroke is higher than in women, but this trend reverses in adults 85 years and older (Petrea et al., 2009). Women also have a higher lifetime risk of stroke (Petrea et al., 2009). Gender differences do not appear with regard to the overall prevalence of hypertension (33.6\% of men and $32.3 \%$ of women), but prevalence is higher for men under 25 (Doumas, Papademetriou, Faselis \& Kokkinos, 2013). Finally, women experience higher rates of arthritis than men ( $26 \%$ vs. $19 \%$ ) while a slightly higher percentage of men have diabetes than women ( $14 \%$ vs. $11 \%)$ (Centers for Disease Control and Prevention, 2014).

Social explanations of differences in men and women's health outcomes have centred on differential access to protective resources, including income and education, as well as exposure to factors that negatively affect health, such as behavioural risk factors, in adulthood (Bird \& Rieker, 2008). Life course research in both the United States and many European countries, however, has consistently linked each of these chronic disease outcomes to childhood socioeconomic circumstances (Blackwell, Hayward, \& Crimmins, 2001; Danese, Pariante, Caspi, Taylor \& Poulton, 2007; Drakopoulos, Lakioti, \& Theodossiou, 2011; Hamil-Luker \& O'Rand, 2007; Johnson \& Schoeni, 2011; Kivimaki et al., 2006; Luo \& Waite, 2005; Maty, Lynch, Raghunathan \& Kaplan, 2008; Mckenzie, Carter, Blakely \& Ivoer, 2011; Mensah \& Hobcraft, 2008). Cumulative dis/advantage is a key framework used to conceptualise this link, referring to a process through which initial disadvantage or advantage is compounded or amplified over time to produce heterogeneity in life course outcomes, such as health (O'Rand, 1996). In other words, the relationship between socioeconomic resources and health begins in early life and is magnified over time. Widening health disparities between advantaged and disadvantaged groups with age suggest that processes of cumulative dis/advantage operate across the life course (Brown, O'Rand, \& Adkins, 2012; 
Dupre, 2007; Lynch, 2003; Shuey \& Elder, 2008; Shuey \& Willson, 2014; Willson et al., 2007).

Early life inequalities in socioeconomic environment are thought to initiate processes of cumulative advantage and disadvantage which lead to divergent trajectories of health across the life course (Corna, 2013). Research also indicates that the timing, duration, and sequencing of childhood exposure to economic hardship are critical for many adulthood outcomes, including health (Shuey \& Willson, 2014; Wagmiller, Lennon, Kuang, Alberti \& Aber, 2006). Existing models of cumulative dis/advantage, however, differentially emphasise the importance of each temporal complexity (see Shuey \& Willson, 2014, for a review). Such approaches also do not take into account heterogeneity in childhood circumstances, ignoring the way in which socioeconomic circumstances can improve or deteriorate throughout childhood, as well as issues of timing related to the onset of disadvantage. Instability in resources in childhood and throughout the life course often occurs, challenging notions of disadvantage that view poverty as a long-term and irreversible state (McDonough \& Berglund, 2003; McDonough, Sacker, \& Wiggins, 2005; Western, Bloome, Sosnaud \& Tach, 2012). Little attention has been given to patterns of change in childhood circumstances. Existing research has also relied heavily on retrospective data and static measures of childhood socioeconomic status (SES). Measures of childhood SES used in previous studies have included: parents' education (e.g. Bowen, 2010; Lemelin et al., 2009; Walsemann et al., 2012), parents' occupation (e.g. Gustafsson \& Hammarstrom, 2012; Hallqvist, Lynch, Bartley, Lang \& Blane, 2004; Lidfelt, Li, Hu, Manson, \& Kawachi, 2007; Maty et al., 2008; Pudrovska \& Anikputa, 2013), family income at a single point in childhood (e.g. Fothergill, Ensminger, Green, Robertson \& Juon, 2009), or some combination of factors, such as receipt of welfare, parental divorce, and father's education (e.g. Montez \& Hayward, 2014; Schafer, Markus \& Ferraro, 2012).

While these studies have made key contributions to our understanding of life course processes of health, they are not able to addresses the effects of dynamic and differing experiences of economic hardship. For example, long-term exposure to childhood disadvantage appears to have the strongest negative effect on adult achievement outcomes and is harmful to health in adulthood (e.g., Shuey \& Willson, 2014; Wagmiller et al., 2006). However, research also suggests that transitions into or out of sustained poverty in childhood have distinct effects on health. For example, deteriorating health in mid-life is more likely among those who transition into sustained economic hardship in childhood, while those whose families move out of poverty during childhood have health trajectories similar to those who never faced economic hardship (Shuey \& Willson, 2014). Accordingly, the timing and duration of experiences of disadvantage in childhood are important to understanding life course trajectories of health. Yet studies tend to draw conclusions about long-term processes based on single snapshots in time (e.g. Pudrovska \& Anikputa, 2013).

Although research demonstrates processes of cumulative advantage and disadvantage begin early in life, it should not be assumed that they operate similarly across groups (George, 2005). Little empirical attention has been given to whether cumulative processes of inequality that begin in childhood may differ for men and women. Such differences are likely given gender differences in biological disease processes, responses to stressors and social conditions, and access to resources (Taylor et al. 2000; Zunzunegui, Alvarado, Béland \& Vissandjee, 2008). For example, women earn less than men even after controlling for education, work experience, and marital status (Hogan \& Perrucci, 2007), dominate temporary and part-time jobs (Fuller \& Vosko, 2008; Prokos, Padavic, \& Schmidt, 2009), and are more likely to experience discontinuity in their employment histories due to their role as primary caregiver (Moen, Robison, \& Fields, 1994). Research that has incorporated gender into the study of childhood disadvantage and adult health suggests that childhood socioeconomic disadvantage predicts psychological distress, depressive symptoms, body mass index (BMI), cardiovascular disease, metabolic syndrome, diabetes and risk of heart attack for women significantly more than for men (Fitzmaurice \& Buka, 2002; Gilman, Kawachi, Pudrovska \& Anishkin, 2013; Gustafsson \& Hammarstrom, 2012; Hamil-Luker \& O’Rand 2007; Lemelin et al., 2009; Lipowicz, Kozieł, Hulanicka \& Kowalisko, 2007; Maty et al., 2008; Walsemann et al., 2012). Pudrovska and 
Anikputa (2013) find evidence of an indirect relationship between early life SES and health through the operation of health behaviours for women only, though it should be noted that early life conditions are only measured at a single point in time. It is likely that cumulative processes differ by gender; however, research has not adequately problematised heterogeneity among women and men to understand how the timing and duration of childhood economic hardship generate health inequality within these groups.

Finally, in examining these processes, it is important to consider multiple measures of health rather than single or monolithic measures for two reasons. First, "different health conditions vary in their etiologies" (Brown et al., 2012, p. 360). Therefore, combining multiple health concerns into an all-encompassing measure risks overlooking the differential accumulation of risk factors that lead to different conditions. Second, the direction and magnitude of gender differences in health vary depending on the condition examined (Denton, Prus, \& Walters, 2004). It is therefore useful to examine multiple health conditions in order to understand similarities and differences in the processes leading to each and to capture important variations by gender. Whereas past studies on cumulative disadvantage, gender and health have considered a single or limited number of health outcomes, the present analysis examines multiple chronic diseases and compares how dynamic experiences of childhood economic hardship are related to each for men and women.

\section{Research questions}

Based on the above considerations, we ask whether trajectories of childhood economic hardship are associated with chronic disease outcomes in midlife for both women and men. In other words, we examine patterns of stability and change in childhood circumstances and their association with processes of cumulative health disadvantage for both women and men. Previous literature suggests childhood disadvantage may be more detrimental for women's health outcomes, so it is possible that the relationship between trajectories of childhood economic hardship and some health outcomes will differ for men and women. We therefore investigate whether the observed relationships between childhood economic hardship and disease onset vary by the health outcome under investigation.

\section{Methods}

\section{Data}

This study uses the US Panel Study of Income Dynamics (PSID), an ongoing survey that began in 1968 with a nationally representative sample of 4,802 families (Panel Study of Income Dynamics, 2013). Information was collected on all household members, primarily from the household head, annually until 1997 when interviewing became biennial. In married families, the 'head' is the husband unless he is incapable of being interviewed and 'wife' is the female in a married or cohabitating couple (McGonagle, Schoeni, Sastry \& Freedman, 2013). The 'head' can also refer to a single female. Annual response rates have ranged from 95 to 98 percent (McGonagle et al., 2013). Interviews are conducted via telephone. The latest wave of available data used in this analysis was collected in 2011. Children of PSID families who leave their parents' homes also become PSID family units, and sample representativeness has been maintained (McGonagle et al., 2013). The multi-generational design of data collection enables adult children to be linked to their parents. Data on childhood socioeconomic environment provided prospectively by parents at the time the child was in the parental home avoids recall bias in childhood conditions. An oversample of families from lowincome neighborhoods was included in the original sample design of the PSID, which enables the differentiation of various experiences of childhood economic hardship. Finally, the PSID contains rich information on various health outcomes, health behaviours, and other important covariates such as income, employment, and marital status. The PSID is one of the few large survey data sets worldwide that has followed multiple generations of families for such a long period of their lives, and as such provides a unique opportunity to prospectively examine the long-term health effects of childhood economic hardship.

\section{Analytic sample}

This study focuses on individuals who were newborn to eight years old in 1968. This age range is 
particularly useful for this analysis as, during the observation period, these individuals enter a stage of the life course in which many health problems begin to emerge. Latent classes of childhood economic hardship experience were estimated for the full sample of these respondents $(\mathrm{N}=4,167)$ using data collected from PSID families from 1968-1977 (see Shuey \& Willson, 2014). The sample used in multivariate analyses includes the subsample of individuals who remained in the study in adulthood and were a PSID 'head' or a 'wife' at the start of the observation period in 1999 as these are the household members that the PSID collects detailed information on in each survey year (Number of individuals=1,229; 697 women, 532 men).

Missing data is a challenge in any longitudinal study. This paper uses survival analysis, which allows the use of unbalanced panels, meaning individuals who attrited from the PSID after the initial observation year $(1999)$ are still included in the analysis. Additionally, one advantage of the PSID is that, unlike retrospective studies, which do not begin studying individuals until much older ages, many selection processes are observable. Multiple studies have extensively examined the effects of the attrition of this cohort of children from the PSID sample on intergenerational models (e.g., those using family income during the respondent's childhood) with covariates that predict adult health outcomes and demonstrate that the PSID maintains its representativeness over time without strong evidence of attrition bias, with the exception that the effect of higher education on sample attrition is stronger than that of health and that female subsamples demonstrate weaker effects of attrition than males (Fitzgerald, 2011; Halliday, Kimmitt, \& Kimmitt, 2012; Meer, Miller, \& Rosen, 2003). Previous research also has found that individuals who experienced childhood poverty are less likely to have remained in the PSID to have an observed health outcome in 1999 when health data began to be collected (see Shuey \& Willson, 2014). Any selective attrition with respect to health will likely lead to an underestimate of the impact of childhood economic hardship. Taken together, this indicates that, while not significantly biased, results from this study are likely conservative estimates of the association of childhood economic hardship and adult health (Shuey \& Willson, 2014).

\section{Measures \\ Disease outcomes}

Four disease outcomes are assessed in this study: high blood pressure, diabetes, arthritis, and a measure consisting of heart attack, heart disease, and stroke. Stroke, heart attack, and heart disease were grouped together due to relatively low prevalence levels in middle age in addition to all affecting the heart and circulatory system (Johnson \& Schoeni 2011). The conditions are measured by responses to the question: "Has a doctor or health professional ever told you that you have had-?" Respondents were asked this question in each survey wave from 1999 to 2011. It is possible for individuals to have comorbidities, but each condition was examined separately and each measure included all those individuals who reported having been diagnosed with that particular health condition. It should be acknowledged that these measures are somewhat non-specific and the measure of arthritis does not distinguish between types of arthritis, which are experienced at different rates by men and women and have differing etiologies. Variation in the experience of arthritis could contribute to gender differences in association with childhood economic hardship, however we believe this is minimal given the similar rates of arthritis among the men and women in the sample. We further discuss the potential implications in the discussion section.

\section{Childhood economic hardship}

Children's histories of economic hardship were analysed over a 10-year period, from 1968 (when the children were 0-8 years old) to 1977. A child was considered to be living in poverty in a given year if the family's total annual income fell below $125 \%$ of the official US poverty threshold.' These indicators and repeated measures of latent class analysis were used to identify subgroups of individuals with similarities in their experience of economic hardship in childhood (see Shuey \& Willson, 2014, for a detailed discussion). Based on fit statistics from the latent class models, and the previous literature (Wagmiller et al., 2006), it was determined that there were four groups into which respondents could be classified: non-poor, moving into poverty, moving out of poverty, and 
long-term poverty. Those who moved into poverty began with a relatively low risk of experiencing poverty, which increased as they reached and transitioned into adolescence, while those who moved out of poverty had a relatively high risk of poverty in early childhood that dropped steadily as they approached late childhood. The long-term poor had a very high probability of exposure to poverty during the entire period of observation (1968-1977), and the non-poor had a very low probability of experiencing poverty during this period.

\section{Other covariates}

Both adult resources and health behaviours are associated with childhood disadvantage and adult health (e.g. Hayward \& Gorman, 2004; Pudrovska \& Anishkin, 2013). All covariates belonging to these categories were included as time varying, with the exception of education (coded as less than high school, high school, some post-secondary, and postsecondary). Employment status and marital status were dichotomised (1=employed; $1=$ married). Total household income was lagged by one year, adjusted for inflation, and logged for each year of observation. Based on considerations from previous literature (Hamil-Luker \& O’Rand, 2007; Kagotho, 2009), frequency of heavy physical activity was coded as $1=$ never engages in physical activity. Drinking and smoking were also dichotomised, with $1=$ drinks one or more drinks per day and 1=current smoker (see Kagotho, 2009). Race/ethnicity, which is strongly associated with both childhood poverty and adult health (Lynch, 2008; National Poverty Center, 2013), was also included as a covariate and coded as nonHispanic black (1) and non-Hispanic white (0). Other racial/ethnic groups were not included due to an inadequate number of observations.

\section{Analytic strategy}

Survival analysis was used to determine how experiences of economic hardship in childhood affect the risk of disease onset in midlife. Multivariate analyses were clustered by person ID. The unit of analysis for all analyses was person-years $(N=15,624)$. Analyses were weighted using the PSID longitudinal weight to adjust for oversampling of low-income families as well as for attrition (McGonagle et al., 2013). The population at risk for each disease outcome was defined as those individuals who had not experienced disease onset for the particular condition under investigation before age 40. Thus, the models predict the likelihood that an individual would develop a condition by the end of the observation period assuming they did not have it by age 40 . This restriction was imposed for two reasons: to address left-censoring, and also, because the focus of this study was to examine disease onset in mid-life.

Multivariate discrete-time hazard models were estimated using logistic regression. These models were appropriate given the fairly large intervals at which the presence of each disease was measured (years) as well as the censoring of some data. Women and men were analysed as separate groups. Such an approach provides greater ease with which to assess the significance of covariate effects within each group (Phillips \& Sweeney, 2005). In addition, it allows us to assess how childhood economic hardship produces heterogeneous health outcomes within women and men, similar to Hamil-Luker and O'Rand (2007). This is particularly important considering our limited understanding of the unique health experiences of men and women who face economic hardship in childhood.

In analyses of temporal dependence, the risk of experiencing the onset of a chronic condition was found to change over time for both women and men; therefore, age was included in the multivariate models as a categorical variable: 40-45 (0) and 46-52 (1). These categories were chosen as they are reflective of a division between early and late middleage. The proportional hazards assumption was also evaluated for women and men. This assumption implies that predictor variables have uniform effects across time, or that there are no interactions between predictors and time (see Allison, 2010; Borucka, 2013). The proportional hazards assumption was violated for women with regard to the effect of poverty class on health, indicating that an interaction term between age and poverty class was necessary for models of women's health to allow for nonproportional hazards (Allison, 2010; Borucka, 2013). The assumption was not violated for men; therefore, models predicting men's outcomes did not include the aforementioned interaction terms. In other words, the effect of childhood economic hardship on disease onset changes over time for women but not men. This prevents testing for significant differences 
across the two groups, as the model specification for women and men is different; however, the focus of this paper is to examine whether and how childhood economic hardship produces heterogeneous health outcomes among women and among men. Results will demonstrate how the timing and duration of childhood economic hardship impacts the health of women and men.

\section{Results}

\section{Descriptive results}

Weighted proportions and means by gender are presented in table 1 . On average, over the observation period, the same percentage of women and men reported having diabetes $(5 \%)$ and stroke, heart disease, or heart attack (3\%). In any given year, about $8 \%$ of men reported arthritis compared to $12 \%$ of women. Over the observation period, men and women experienced similar rates of high blood

pressure, at $17 \%$ and $16 \%$, respectively. Rates of childhood economic hardship were roughly similar across women and men. High school graduates make up the largest proportion of education categories for both men and women (39\% and 34\%, respectively). More men (43\%) than women (25\%) reported drinking one or more drinks per day and more women (33\%) than men (25\%) reported never exercising. Smoking rates were similar at $25 \%$ for women and $23 \%$ for men. 
Table 1. Descriptive statistics by gender (weighted), 1999-2011 PSID

\begin{tabular}{|c|c|c|}
\hline Variable & Women & Men \\
\hline \multicolumn{3}{|l|}{ Diabetes } \\
\hline Yes & 0.05 & 0.05 \\
\hline No & 0.95 & 0.95 \\
\hline \multicolumn{3}{|l|}{ High blood pressure } \\
\hline Yes & 0.16 & 0.17 \\
\hline No & 0.84 & 0.83 \\
\hline \multicolumn{3}{|l|}{ Arthritis } \\
\hline Yes & 0.12 & 0.08 \\
\hline No & 0.88 & 0.82 \\
\hline \multicolumn{3}{|c|}{ Stroke, heart disease, heart attack } \\
\hline Yes & 0.03 & 0.03 \\
\hline No & 0.97 & 0.97 \\
\hline \multicolumn{3}{|l|}{ Childhood poverty status } \\
\hline Non-poor & 0.75 & 0.75 \\
\hline Move into poverty & 0.05 & 0.04 \\
\hline Long-term poor & 0.10 & 0.08 \\
\hline Move out of poverty & 0.09 & 0.13 \\
\hline \multicolumn{3}{|l|}{ Race/Ethnicity } \\
\hline $\begin{array}{l}\text { Non-Hispanic } \\
\text { Black }\end{array}$ & 0.27 & 0.20 \\
\hline $\begin{array}{l}\text { Non-Hispanic } \\
\text { White }\end{array}$ & 0.73 & 0.80 \\
\hline Age & 41.37 & 41.27 \\
\hline \multicolumn{3}{|l|}{ Adult education } \\
\hline$<$ High school & 0.10 & 0.07 \\
\hline High school & 0.34 & 0.39 \\
\hline Some post-secondary & 0.29 & 0.22 \\
\hline Post-secondary & 0.27 & 0.32 \\
\hline \multicolumn{3}{|l|}{ Employment status } \\
\hline Employed & 0.22 & 0.90 \\
\hline Not employed & 0.78 & 0.10 \\
\hline \multicolumn{3}{|l|}{ Marital status } \\
\hline Married & 0.66 & 0.76 \\
\hline Not married & 0.34 & 0.24 \\
\hline Income (median) & 60851 & 78087 \\
\hline \multicolumn{3}{|l|}{ Smoking status } \\
\hline Yes & 0.25 & 0.23 \\
\hline \multicolumn{3}{|l|}{ Drinking frequency } \\
\hline 1+/Day & 0.25 & 0.43 \\
\hline \multicolumn{3}{|l|}{ Physical activity } \\
\hline Never engages & 0.33 & 0.25 \\
\hline$N$ & 697 & 532 \\
\hline$N($ person-years) & 8848 & 6776 \\
\hline
\end{tabular}

Notes: Proportions for disease outcomes refer to the average proportion in each category over the observation period. Data were converted into person-year format required for survival analysis. 


\section{Multivariate analyses}

In all models for women, the reference group is women in early midlife (aged 40-45) who did not experience economic hardship in childhood. The comparison group is women in late midlife (aged 4652) who have experienced some form of poverty.

\section{Diabetes (table 2)}

In model 1, women in late midlife who experienced long-term poverty in childhood were approximately eight times more likely to experience the onset of diabetes by the end of the observation period compared to their younger counterparts who did not experience poverty $(p=0.006)$. In addition, older women who moved out of poverty in late childhood were still 16 times more likely to experience the onset of diabetes $(p=0.022)$. Conversely, younger women were less likely to experience diabetes even if they experienced long-term poverty as children
$(\mathrm{OR}=0.20 ; \mathrm{p}=0.026)$. With the introduction of adult resources, health behaviours and other covariates, women belonging to both of these poverty classes remained more likely to experience the onset of diabetes by the end of the observation period relative to younger women who did not experience poverty (OR=9.01, $p=0.007 ; \mathrm{OR}=12.97, \mathrm{p}=0.032$ ). Stated as probability, women who experienced long-term poverty had a $90 \%$ chance of developing diabetes by the end of the observation period and women who moved out of poverty had a $93 \%$ chance. For women, then, the effects of childhood economic hardship on diabetes onset in midlife vary by age, with the impact of long-term poverty and poverty in early childhood manifesting in late middle age. Conversely, childhood economic hardship was not a significant predictor of diabetes onset for men. 
Table 2. Discrete-time logistic regression estimated effects of childhood economic hardship on the risk of onset of Diabetes within 12 years, by gender: 1999-2011 PSID

\begin{tabular}{|c|c|c|c|c|c|c|c|c|c|c|c|c|c|c|c|c|}
\hline \multirow{3}{*}{$\begin{array}{l}\text { Independent } \\
\text { variable }\end{array}$} & \multicolumn{4}{|c|}{ Model 1} & \multicolumn{4}{|c|}{ Model $2^{a}$} & \multicolumn{4}{|c|}{ Model $3^{b}$} & \multicolumn{4}{|c|}{ Model $4^{c}$} \\
\hline & \multicolumn{2}{|c|}{ Women } & \multicolumn{2}{|c|}{ Men } & \multicolumn{2}{|c|}{ Women } & \multicolumn{2}{|c|}{ Men } & \multicolumn{2}{|c|}{ Women } & \multicolumn{2}{|c|}{ Men } & \multicolumn{2}{|c|}{ Women } & \multicolumn{2}{|c|}{ Men } \\
\hline & $\begin{array}{l}\text { Odds } \\
\text { ratio }\end{array}$ & $\begin{array}{c}\mathrm{p}- \\
\text { value }\end{array}$ & $\begin{array}{l}\text { Odds } \\
\text { ratio }\end{array}$ & $\begin{array}{c}\mathrm{p}- \\
\text { value }\end{array}$ & $\begin{array}{l}\text { Odds } \\
\text { ratio }\end{array}$ & $\begin{array}{c}\mathrm{p}- \\
\text { value }\end{array}$ & $\begin{array}{l}\text { Odds } \\
\text { ratio }\end{array}$ & $\begin{array}{c}\mathrm{p}- \\
\text { value }\end{array}$ & $\begin{array}{l}\text { Odds } \\
\text { ratio }\end{array}$ & $\begin{array}{c}\mathrm{p}- \\
\text { value }\end{array}$ & $\begin{array}{l}\text { Odds } \\
\text { ratio }\end{array}$ & $\begin{array}{c}\mathrm{p}- \\
\text { value }\end{array}$ & $\begin{array}{l}\text { Odds } \\
\text { ratio }\end{array}$ & $\begin{array}{c}p- \\
\text { value }\end{array}$ & $\begin{array}{l}\text { Odds } \\
\text { ratio }\end{array}$ & $\begin{array}{c}\mathrm{p}- \\
\text { value }\end{array}$ \\
\hline \multicolumn{17}{|l|}{$\begin{array}{l}\text { Childhood } \\
\text { economic } \\
\text { hardship (non- } \\
\text { poor) }\end{array}$} \\
\hline $\begin{array}{l}\text { Move into } \\
\text { poverty }\end{array}$ & 0.92 & 0.889 & 2.15 & 0.285 & 1.17 & 0.819 & 1.75 & 0.371 & 0.94 & 0.929 & 1.83 & 0.350 & 0.70 & 0.652 & 1.54 & 0.433 \\
\hline $\begin{array}{l}\text { Long-term } \\
\text { poverty }\end{array}$ & 0.20 & 0.026 & 0.76 & 0.289 & 0.17 & 0.019 & 0.73 & 0.422 & 0.15 & 0.011 & 0.72 & 0.401 & 0.10 & 0.007 & 0.49 & 0.168 \\
\hline $\begin{array}{l}\text { Move out of } \\
\text { poverty }\end{array}$ & 0.15 & 0.081 & 2.21 & 0.279 & 0.15 & 0.126 & 1.78 & 0.429 & 0.13 & 0.091 & 1.63 & 0.518 & 0.10 & 0.051 & 1.29 & 0.718 \\
\hline \multicolumn{17}{|l|}{ Age (40-45) } \\
\hline 46-52 & 2.04 & 0.096 & 7.42 & 0.000 & 2.44 & 0.045 & 8.90 & 0.000 & 2.51 & 0.076 & 9.01 & 0.000 & 2.57 & 0.062 & 9.82 & 0.000 \\
\hline \multicolumn{17}{|l|}{$\begin{array}{l}\text { Childhood } \\
\text { economic } \\
\text { hardship } X \text { age }\end{array}$} \\
\hline $\begin{array}{l}\text { Move into } \\
\text { poverty } \times 46- \\
52\end{array}$ & 1.06 & 0.921 & & & 0.76 & 0.688 & & & 1.02 & 0.982 & & & 0.90 & 0.887 & & \\
\hline $\begin{array}{l}\text { Long-term } \\
\text { poverty } \times 46 \text { - } \\
52\end{array}$ & 8.17 & 0.006 & & & 8.43 & 0.006 & & & 9.07 & 0.008 & & & 9.01 & 0.007 & & \\
\hline $\begin{array}{l}\text { Move out of } \\
\text { poverty X 46- } \\
52\end{array}$ & 15.67 & 0.022 & & & 12.37 & 0.034 & & & 11.88 & 0.038 & & & 12.97 & 0.032 & & \\
\hline Constant & 0.29 & 0.002 & 0.12 & 0.000 & 19.75 & 0.190 & 0.00 & 0.002 & 6.27 & 0.465 & 0.00 & 0.002 & 6.77 & 0.437 & 0.00 & 0.002 \\
\hline
\end{tabular}

Notes:

Number of observations (women) $=810$. Number of observations $($ men $)=594$.

${ }^{a}$ Model 2 controls for adult resources: education, income, employment status, and marital status.

${ }^{\mathrm{b}}$ Model 3 controls for the variables specified in Model 2 and adds adult health behaviours: smoking, drinking, and physical activity.

${ }^{c}$ Model 4 controls for the variables specified in Models 2 and 3 and adds race/ethnicity. 
Table 3. Discrete-time logistic regression estimated effects of childhood economic hardship on the risk of onset of high blood pressure within 12 years, by gender: 1999-2011 PSID

Independent

Model $2^{\text {a }}$

Model $3^{\text {b }}$

Model $4^{\mathrm{c}}$

\begin{tabular}{|c|c|c|c|c|c|c|c|c|c|c|c|c|c|c|c|c|}
\hline & \multicolumn{2}{|c|}{ Women } & \multicolumn{2}{|c|}{ Men } & \multicolumn{2}{|c|}{ Women } & \multicolumn{2}{|c|}{ Men } & \multicolumn{2}{|c|}{ Women } & \multicolumn{2}{|c|}{ Men } & \multicolumn{2}{|c|}{ Women } & \multicolumn{2}{|c|}{ Men } \\
\hline & $\begin{array}{l}\text { Odds } \\
\text { ratio }\end{array}$ & $\begin{array}{c}\mathrm{p}- \\
\text { value }\end{array}$ & $\begin{array}{l}\text { Odds } \\
\text { ratio }\end{array}$ & $\begin{array}{c}\mathrm{p}- \\
\text { value }\end{array}$ & $\begin{array}{l}\text { Odds } \\
\text { ratio }\end{array}$ & $\begin{array}{c}\mathrm{p}- \\
\text { value }\end{array}$ & $\begin{array}{l}\text { Odds } \\
\text { ratio }\end{array}$ & $\begin{array}{c}\mathrm{p}- \\
\text { value }\end{array}$ & $\begin{array}{l}\text { Odds } \\
\text { ratio }\end{array}$ & $\begin{array}{c}\mathrm{p}- \\
\text { value }\end{array}$ & $\begin{array}{l}\text { Odds } \\
\text { ratio }\end{array}$ & $\begin{array}{c}\mathrm{p}- \\
\text { value }\end{array}$ & $\begin{array}{l}\text { Odds } \\
\text { ratio }\end{array}$ & $\begin{array}{c}\mathrm{p}- \\
\text { value }\end{array}$ & $\begin{array}{l}\text { Odds } \\
\text { ratio }\end{array}$ & $\begin{array}{c}\mathrm{p}- \\
\text { value }\end{array}$ \\
\hline \multicolumn{17}{|l|}{$\begin{array}{l}\text { Childhood } \\
\text { economic } \\
\text { hardship (Non- } \\
\text { poor) }\end{array}$} \\
\hline $\begin{array}{l}\text { Move into } \\
\text { poverty }\end{array}$ & 1.13 & 0.758 & 1.52 & 0.280 & 1.22 & 0.635 & 1.65 & 0.200 & 1.40 & 0.412 & 1.63 & 0.235 & 1.50 & 0.321 & 1.66 & 0.228 \\
\hline $\begin{array}{l}\text { Long-term } \\
\text { poverty }\end{array}$ & 0.65 & 0.108 & 0.97 & 0.861 & 0.72 & 0.259 & 0.98 & 0.937 & 0.78 & 0.396 & 1.01 & 0.953 & 0.85 & 0.589 & 0.95 & 0.838 \\
\hline $\begin{array}{l}\text { Move out of } \\
\text { poverty }\end{array}$ & 0.59 & 0.192 & 0.95 & 0.808 & 0.68 & 0.340 & 1.03 & 0.873 & 0.70 & 0.392 & 1.03 & 0.891 & 0.76 & 0.504 & 0.96 & 0.897 \\
\hline \multicolumn{17}{|l|}{ Age (40-45) } \\
\hline $46-52$ & 5.90 & 0.000 & 7.69 & 0.000 & 6.85 & 0.000 & 8.30 & 0.000 & 6.65 & 0.000 & 8.17 & 0.000 & 6.70 & 0.000 & 8.17 & 0.000 \\
\hline \multicolumn{17}{|l|}{$\begin{array}{l}\text { Childhood } \\
\text { economic } \\
\text { hardship X age }\end{array}$} \\
\hline $\begin{array}{l}\text { Move into } \\
\text { poverty } \times 46- \\
52\end{array}$ & 0.62 & 0.289 & & & 0.53 & 0.170 & & & 0.55 & 0.191 & & & 0.55 & 0.194 & & \\
\hline $\begin{array}{l}\text { Long-term } \\
\text { Poverty X 46- } \\
52\end{array}$ & 1.51 & 0.191 & & & 1.31 & 0.394 & & & 1.34 & 0.366 & & & 1.33 & 0.379 & & \\
\hline $\begin{array}{l}\text { Move out of } \\
\text { poverty X 46- } \\
52\end{array}$ & 1.81 & 0.202 & & & 1.52 & 0.380 & & & 1.65 & 0.294 & & & 1.62 & 0.310 & & \\
\hline Constant & 0.17 & 0.000 & 0.12 & 0.000 & 0.20 & 0.082 & 0.17 & 0.049 & 0.26 & 0.147 & 0.17 & 0.062 & 0.30 & 0.225 & 0.15 & 0.055 \\
\hline
\end{tabular}

Notes:

Number of observations (women) = 2592. Number of observations (men) $=2020$.

${ }^{a}$ Model 2 controls for adult resources: education, income, employment status, and marital status.

${ }^{\mathrm{b}}$ Model 3 controls for the variables specified in Model 2 and adds adult health behaviours: smoking, drinking, and physical activity.

${ }^{c}$ Model 4 controls for the variables specified in Models 2 and 3 and adds race/ethnicity. 


\section{High blood pressure (table 3)}

Childhood economic hardship was not a significant predictor of the midlife onset of high blood pressure for women or men in any of the four models.

\section{Arthritis (table 4)}

In model 1, women in late middle-age who moved out of poverty were about six times more likely to experience arthritis compared to their younger peers who did not experience childhood poverty $(p=0.006)$. This relationship persisted when adult resources, health behaviours, and race/ethnicity were taken into account (OR=7.75, $p=0.011$ in Model 4). In other words, these women had an $89 \%$ chance of developing arthritis. For men, however, childhood economic hardship was not a significant predictor of arthritis onset in midlife.

\section{Stroke, heart disease, heart attack (table 5)}

In model 1 , women in late midlife who lived in long-term poverty as children were about six times more likely to experience stroke, heart disease, or a heart attack compared to their younger peers who did not experience childhood poverty $(p=0.001)$. This relationship remained the same controlling for adult resources, health behaviours, and race/ethnicity (OR=6.02, $p=0.002$; Model 4). That is, these women had an $86 \%$ probability of developing stroke, heart disease, or heart attack. For men, having moved into poverty in childhood was associated with being three times more likely to experience stroke, heart disease, or a heart attack by the end of the observation period $(p=0.004 ;$ model 1$)$. With introduction of adult resources in model 2 , this increased to four times more likely $(p=0.001)$. When health behaviours were added in model 3, men who moved into poverty as children were nearly six times more likely to experience stroke, heart disease, or a heart attack compared to their non-poor peers $(p=0.001)$. This remained true in model 4 . 
Table 4. Discrete-time logistic regression estimated effects of childhood economic hardship on the risk of onset of arthritis within 12 Years, by gender: 1999-2011 PSID

\begin{tabular}{|c|c|c|c|c|c|c|c|c|c|c|c|c|c|c|c|c|}
\hline \multirow{3}{*}{$\begin{array}{l}\text { Independent } \\
\text { variable }\end{array}$} & \multicolumn{4}{|c|}{ Model 1} & \multicolumn{4}{|c|}{ Model $2^{\text {a }}$} & \multicolumn{4}{|c|}{ Model $3^{b}$} & \multicolumn{4}{|c|}{ Model $4^{c}$} \\
\hline & \multicolumn{2}{|c|}{ Women } & \multicolumn{2}{|c|}{ Men } & \multicolumn{2}{|c|}{ Women } & \multicolumn{2}{|c|}{ Men } & \multicolumn{2}{|c|}{ Women } & \multicolumn{2}{|c|}{ Men } & \multicolumn{2}{|c|}{ Women } & \multicolumn{2}{|c|}{ Men } \\
\hline & $\begin{array}{l}\text { Odds } \\
\text { ratio }\end{array}$ & $\begin{array}{c}\mathrm{p}- \\
\text { value }\end{array}$ & $\begin{array}{l}\text { Odds } \\
\text { ratio }\end{array}$ & $\begin{array}{c}\mathrm{p}- \\
\text { value }\end{array}$ & $\begin{array}{l}\text { Odds } \\
\text { ratio }\end{array}$ & $\begin{array}{c}\mathrm{p}- \\
\text { value }\end{array}$ & $\begin{array}{l}\text { Odds } \\
\text { ratio }\end{array}$ & $\begin{array}{c}\mathrm{p}- \\
\text { value }\end{array}$ & $\begin{array}{l}\text { Odds } \\
\text { ratio }\end{array}$ & $\begin{array}{c}\mathrm{p}- \\
\text { value }\end{array}$ & $\begin{array}{l}\text { Odds } \\
\text { ratio }\end{array}$ & $\begin{array}{c}\mathrm{p}- \\
\text { value }\end{array}$ & $\begin{array}{l}\text { Odds } \\
\text { ratio }\end{array}$ & $\begin{array}{c}\mathrm{p}- \\
\text { value }\end{array}$ & $\begin{array}{l}\text { Odds } \\
\text { ratio }\end{array}$ & $\begin{array}{c}\mathrm{p}- \\
\text { value }\end{array}$ \\
\hline \multicolumn{17}{|l|}{$\begin{array}{l}\text { Childhood } \\
\text { economic } \\
\text { hardship (Non- } \\
\text { poor) }\end{array}$} \\
\hline $\begin{array}{l}\text { Move into } \\
\text { poverty }\end{array}$ & 0.35 & 0.085 & 0.82 & 0.535 & 0.30 & 0.043 & 0.64 & 0.233 & 0.29 & 0.034 & 0.67 & 0.340 & 0.31 & 0.053 & 0.66 & 0.297 \\
\hline $\begin{array}{l}\text { Long-term } \\
\text { poverty }\end{array}$ & 0.55 & 0.066 & 0.77 & 0.268 & 0.49 & 0.033 & 0.65 & 0.193 & 0.48 & 0.030 & 0.65 & 0.219 & 0.54 & 0.105 & 0.47 & 0.108 \\
\hline $\begin{array}{l}\text { Move out of } \\
\text { poverty }\end{array}$ & 0.19 & 0.005 & 1.62 & 0.203 & 0.18 & 0.008 & 1.39 & 0.435 & 0.17 & 0.008 & 1.47 & 0.357 & 0.19 & 0.011 & 1.07 & 0.901 \\
\hline \multicolumn{17}{|l|}{ Age (40-45) } \\
\hline $\begin{array}{l}46-52 \\
\text { Childhood } \\
\text { economic } \\
\text { hardship X age }\end{array}$ & 4.03 & 0.000 & 6.07 & 0.000 & 4.38 & 0.000 & 6.40 & 0.000 & 4.60 & 0.000 & 6.43 & 0.000 & 4.57 & 0.000 & 6.62 & 0.000 \\
\hline $\begin{array}{l}\text { Move into } \\
\text { poverty } \times 46 \text { - } \\
52\end{array}$ & 2.56 & 0.167 & & & 2.57 & 0.162 & & & 2.49 & 0.174 & & & 2.58 & 0.151 & & \\
\hline $\begin{array}{l}\text { Long-term } \\
\text { poverty X 46- } \\
52\end{array}$ & 1.63 & 0.209 & & & 1.46 & 0.329 & & & 1.45 & 0.333 & & & 1.48 & 0.307 & & \\
\hline $\begin{array}{l}\text { Move out of } \\
\text { poverty X 46- } \\
52\end{array}$ & 6.18 & 0.006 & & & 5.55 & 0.011 & & & 5.53 & 0.012 & & & 5.75 & 0.011 & & \\
\hline Constant & 0.27 & 0.000 & 0.15 & 0.000 & 1.11 & 0.931 & 0.30 & 0.481 & 1.03 & 0.981 & 0.18 & 0.330 & 1.39 & 0.804 & 0.18 & 0.330 \\
\hline
\end{tabular}

Number of observations (women) $=1944$. Number of observations (men) $=950$

${ }^{a}$ Model 2 controls for adult resources: education, income, employment status, and marital status.

${ }^{\mathrm{b}}$ Model 3 controls for the variables specified in Model 2 and adds adult health behaviours: smoking, drinking, and physical activity.

${ }^{c}$ Model 4 controls for the variables specified in Models 2 and 3 and adds race/ethnicity. 
Table 5. Discrete-time logistic regression estimated effects of childhood economic hardship on the risk of onset of stroke, heart disease, heart attack within 12 Years, by Gender: 1999-2011 PSID

\begin{tabular}{|c|c|c|c|c|c|c|c|c|c|c|c|c|c|c|c|c|}
\hline \multirow{3}{*}{$\begin{array}{l}\text { Independent } \\
\text { variable }\end{array}$} & \multicolumn{4}{|c|}{ Model 1} & \multicolumn{4}{|c|}{ Model $2^{a}$} & \multicolumn{4}{|c|}{ Model $3^{b}$} & \multicolumn{4}{|c|}{ Model $4^{c}$} \\
\hline & \multicolumn{2}{|c|}{ Women } & \multicolumn{2}{|c|}{ Men } & \multicolumn{2}{|c|}{ Women } & \multicolumn{2}{|c|}{ Men } & \multicolumn{2}{|c|}{ Women } & \multicolumn{2}{|c|}{ Men } & \multicolumn{2}{|c|}{ Women } & \multicolumn{2}{|c|}{ Men } \\
\hline & $\begin{array}{l}\text { Odds } \\
\text { ratio }\end{array}$ & $\begin{array}{c}\mathrm{p}- \\
\text { value }\end{array}$ & $\begin{array}{l}\text { Odds } \\
\text { ratio }\end{array}$ & $\begin{array}{c}\mathrm{p}- \\
\text { value }\end{array}$ & $\begin{array}{l}\text { Odds } \\
\text { ratio }\end{array}$ & $\begin{array}{c}\mathrm{p}- \\
\text { value }\end{array}$ & $\begin{array}{l}\text { Odds } \\
\text { ratio }\end{array}$ & $\begin{array}{c}\mathrm{p}- \\
\text { value }\end{array}$ & $\begin{array}{l}\text { Odds } \\
\text { ratio }\end{array}$ & $\begin{array}{c}\mathrm{p}- \\
\text { value }\end{array}$ & $\begin{array}{l}\text { Odds } \\
\text { ratio }\end{array}$ & $\begin{array}{c}\mathrm{p}- \\
\text { value }\end{array}$ & $\begin{array}{l}\text { Odds } \\
\text { ratio }\end{array}$ & $\begin{array}{c}\mathrm{p}- \\
\text { value }\end{array}$ & $\begin{array}{l}\text { Odds } \\
\text { ratio }\end{array}$ & $\begin{array}{c}\mathrm{p}- \\
\text { value }\end{array}$ \\
\hline \multicolumn{17}{|l|}{$\begin{array}{l}\text { Childhood } \\
\text { economic } \\
\text { hardship (Non- } \\
\text { poor) }\end{array}$} \\
\hline $\begin{array}{l}\text { Move into } \\
\text { poverty }\end{array}$ & 1.35 & 0.534 & 2.92 & 0.004 & 1.43 & 0.513 & 4.03 & 0.001 & 1.99 & 0.215 & 5.83 & 0.001 & 2.03 & 0.217 & 5.99 & 0.000 \\
\hline $\begin{array}{l}\text { Long-term } \\
\text { poverty }\end{array}$ & 0.33 & 0.022 & 0.73 & 0.399 & 0.32 & 0.053 & 0.43 & 0.146 & 0.39 & 0.110 & 0.44 & 0.158 & 0.40 & 0.173 & 0.14 & 0.000 \\
\hline $\begin{array}{l}\text { Move out of } \\
\text { poverty }\end{array}$ & 0.71 & 0.421 & 1.06 & 0.915 & 0.76 & 0.540 & 1.09 & 0.864 & 0.76 & 0.542 & 1.05 & 0.928 & 0.78 & 0.646 & 0.44 & 0.18 \\
\hline \multicolumn{17}{|l|}{ Age (40-45) } \\
\hline $46-52$ & 2.13 & 0.015 & 4.52 & 0.000 & 2.35 & 0.008 & 6.21 & 0.000 & 2.42 & 0.012 & 5.95 & 0.000 & 2.40 & 0.013 & 8.91 & 0.000 \\
\hline \multicolumn{17}{|l|}{$\begin{array}{l}\text { Childhood } \\
\text { economic } \\
\text { hardship X age }\end{array}$} \\
\hline $\begin{array}{l}\text { Move into } \\
\text { poverty } \times 46 \text { - } \\
52\end{array}$ & 1.02 & 0.986 & & & 1.02 & 0.985 & & & 0.78 & 0.793 & & & 0.79 & 0.808 & & \\
\hline $\begin{array}{l}\text { Long-term } \\
\text { poverty X 46- } \\
52\end{array}$ & 6.07 & 0.001 & & & 5.80 & 0.002 & & & 5.98 & 0.002 & & & 6.02 & 0.002 & & \\
\hline $\begin{array}{l}\text { Move out of } \\
\text { poverty } \times 46- \\
52\end{array}$ & 2.71 & 0.093 & & & 2.62 & 0.143 & & & 3.24 & 0.102 & & & 3.24 & 1.00 & & \\
\hline Constant & 0.34 & 0.000 & 0.23 & 0.000 & 3.08 & 0.532 & 1.43 & 0.883 & 5.92 & 0.279 & 25.08 & 0.285 & 6.13 & 0.302 & 15.91 & 0.353 \\
\hline
\end{tabular}

Number of observations ( women) $=486$. Number of observations $($ men $)=356$.

${ }^{a}$ Model 2 controls for adult resources: education, income, employment status, and marital status.

${ }^{\mathrm{b}}$ Model 3 controls for the variables specified in Model 2 and adds adult health behaviours: smoking, drinking, and physical activity.

${ }^{c}$ Model 4 controls for the variables specified in Models 2 and 3 and adds race/ethnicity. 


\section{Discussion}

While studies of gender and health have typically focused on 'explaining away' the gender difference, we take a different approach to this commonly investigated phenomenon through examining how patterns of change and stability in childhood economic hardship initiate processes of disadvantage in health among women and men rather than between them. Although men and women in this study experienced chronic disease at similar rates, the cumulative processes leading to heterogeneity within each group were quite different. Consistent with previous US and European literature, in this analysis childhood economic hardship differentiated between women at low and high risk of chronic disease in midlife but not men (e.g. Gustafsson \& Hammarstrom, 2012; Lemelin et al., 2009; Lipowicz et al., 2007; Walsemann et al., 2012). One exception was stroke, heart disease, and heart attack, where childhood economic hardship increased risk of onset for both men and women. This inconsistency with previous research could be the result of a more nuanced and prospective measure of childhood economic hardship than was used in previous studies (e.g. Hamil-Luker \& O'Rand, 2007).

Overall, our findings indicate that it is not just longterm poverty that matters for women's health outcomes, but poverty may have lasting effects even after leaving it. For example, long-term poverty in childhood significantly predicted women's risk of onset for diabetes and stroke, heart disease, and heart attack. In addition, women who began life in poverty but moved out of poverty in childhood also were more likely than those who were never in poverty to experience diabetes onset in late midlife, as well as arthritis. These findings reveal the importance of measuring childhood poverty as dynamic rather than capturing it at a single point in time or as a retrospective global measure. Research on the impact of SES in early life on later life health that relies on one measure of parents' SES (e.g. Beebe-Dimmer et al., 2004), and retrospective accounts of childhood SES, which increase the likelihood of recall bias may underestimate the effects of childhood context (e.g. Galobardes et al., 2004). Thus, while research in many Western countries finds disparities in adult health outcomes to be linked to childhood circumstances (e.g. Drakopoulos, Lakioti, \& Theodossiou, 2011; Gustafsson \& Hammarström, 2012; Johnson \& Schoeni, 2011; Kivimaki et al., 2006; Mckenzie et al., 2011; Mensah \& Hobcraft, 2008), our study provides support for a more nuanced and dynamic conceptualisation and measurement of childhood poverty with implications for how we understand processes of status and health.

These analyses demonstrate that the timing and duration of childhood economic hardship is associated with more negative health outcomes in later midlife for women than men. It should be noted that findings remained significant and odds ratios remained about the same even after adjustment for covariates. This may be indicative of a direct effect of childhood poverty, as hypothesised by other research (e.g. Diprete \& Elrich, 2006). Nevertheless, future research should continue to examine the mechanisms through which childhood poverty affects adult health as this was beyond the scope of this paper. Potential pathways through which childhood disadvantage affects later life health include negative changes in physiology and metabolism in utero (DeBoo \& Harding, 2006), disruptions to biological functioning (Miller, Chen \& Parker, 2011), increased stress levels (Miech \& Shanahan, 2000), and continuous exposure to health-compromising circumstances as a result of disadvantage (Willson, Shuey \& Elder, 2007).

Socioeconomic conditions in childhood may be more detrimental to women's health outcomes, in particular, because they are less likely to experience social mobility over the life course than men (Walsemann et al., 2012). In other words, the impact of childhood disadvantage on health is eventually less important for men because of their greater resource attainment in adulthood. Childhood adversity is also associated with reduced accumulation of life course capital, and this relationship is stronger for women (Hamil-Luker \& O'Rand, 2007). Additionally, qualitative research suggests a greater accumulation of adversity over the life course for women than men (deVries \& Watt, 1996). Disadvantage experienced in childhood may therefore continue to accumulate for women over the life course based on the structuring of opportunities and life chances by gender (Hunt \& Annandale, 1999). For example, through disadvantages in paid and unpaid labour, 
discriminatory experiences, stress, and caregiving burdens, the impact of childhood economic hardship on health may be aggravated (Coltrane, 2000; Lundberg, 1996; Lundberg \& Parr, 2000; Turner \& Avison, 2003; Turner, Wheaton \& Lloyd, 1995). While gender differences in health are consistent across many European countries and the US (Crimmins, Kim, \& Sole-Auro, 2010), the relationship between socioeconomic resources, gender and health can very by welfare regime (Bambra et al., 2009). Due to the unique nature of the social welfare and health care systems in the US, it is possible that the association between childhood economic hardship and adult health found in this analysis may be more pronounced than would be found in countries where SES and health are not as strongly linked. Future research should continue to assess pathways through which heterogeneous trajectories of childhood economic hardship are associated with health among women.

As expected, the observed relationships between childhood economic hardship and health for both men and women also depended on the health outcome examined. For example, women who began childhood with a high risk of exposure to poverty but moved out of poverty as they reached adolescence were more likely to have arthritis in late midlife; in contrast, long-term poverty was most consequential for women's heart disease outcomes. For men, a move in to poverty in childhood predicted stroke, heart disease, and heart attack in midlife, but childhood economic hardship was not a significant predictor of men's other health outcomes. These findings are not surprising given that different health outcomes often have different etiologies (Brown et al., 2012), and also provide support for the dynamic measurement of childhood economic hardship in future research given the nuanced effects on health that emerge (Shuey \& Willson, 2014).

This study has several limitations. First, as in any longitudinal analysis that covers a large span of time, there is the potential for unobserved heterogeneity resulting from panel attrition; although there is comprehensive evidence that suggests that the observed relationships were not seriously biased due to attrition, they were potentially weakened. Second, childhood disadvantage was conceptualised and measured as economic hardship based on household income. Future research may also consider such experiences as change in family structure. Based on available disease measures, we were also unable to account for different types of particular diseases, which is most relevant for the measure of arthritis (e.g. osteo vs. rheumatoid arthritis); however, analyses were stratified by gender and disease given known gender differences in patterns of disease. Research demonstrates that women more often experience acute and chronic conditions while men experience more life-threatening disease (Bird \& Rieker, 2008). Not surprisingly, we find childhood disadvantage to be associated with diabetes and arthritis for women, and stroke, heart disease, and heart attack for men. Further, men and women in the sample actually reported similar rates of these diseases. The disease measures used were also selfreports of doctor diagnoses. Research demonstrates that lower income individuals are less likely to regularly seek care or visit a doctor (Dubay \& Lebrun, 2012), meaning results may be conservative. Finally, this study considers the onset of four physical disease outcomes. Future research should also examine other physical and mental health outcomes.

Despite these limitations, this study is the first to examine whether the timing and duration of childhood exposure to economic hardship generates a process of cumulative disadvantage in health for both men and women. It has demonstrated the importance of measuring poverty as dynamic rather than static in that long-term and an initial high risk of childhood poverty appeared to be more consequential than other experiences of childhood economic hardship for women. Indeed, when childhood economic hardship is measured as dynamic, nuances emerge that have not been captured by other studies. Although this study is unable to concretely determine why different experiences of economic hardship in childhood matter for different disease outcomes, it clearly demonstrates that change and stability in childhood socioeconomic circumstances matter. Further, the link between childhood economic hardship and longterm negative health consequences may be more relevant to women's health over the life course.

Rather than focusing on how socioeconomic circumstances in adulthood explain differences in health between men and women, we focus on how 
childhood adversity differentiates risk of onset within each group. Instead of simply controlling for gender, we explore the unique patterns of cumulative disadvantage among women and men. In so doing, we not only find childhood economic hardship to produce heterogeneity in women's chronic disease outcomes (Hamil-Luker \& O'Rand, 2007), but also, that the impact of childhood poverty varies by age for women. Little empirical research has examined whether the process of cumulative disadvantage is the same across different sub-groups of the population over time or when the effects of childhood economic hardship may emerge for particular groups. This study suggests that cumulative disadvantage may be a gendered process, with agedependent effects and heterogeneous health outcomes generally emerging for women, but not for men.

\section{Acknowledgements}

This study was supported by an operating grant from Canadian Institutes of Health Research as well as an Ontario Women's Health Scholars Award to Nicole Etherington. The collection of data used in this study was partly supported by the National Institutes of Health under grant number R01 HD069609 and the National Science Foundation under award number 1157698. The authors wish to thank the anonymous reviewers for their constructive and invaluable comments.

\section{References}

Allison, P.D. (2010). Survival Analysis. Retrieved from http://www.statisticalhorizons.com/wpcontent/uploads/2012/01/Allison_SurvivalAnalysis.pdf

Bambra, C., Pope, D., Swami, V., Stanistreet, D., Roskam, A., Kunst, A., \& Scott-Samuel, A. (2009). Gender, health inequalities and welfare state regimes: a cross-national study of 13 European countries. Journal of Epidemiology \& Community Health, 63, 38044. http://dx.doi.org/10.1136/jech.2007.070292

Blackwell, D. L., Hayward, M., \& Crimmins, E. (2001). Does childhood health affect chronic morbidity in later life? Social Science \& Medicine, 52(8), 1269-1284. http://dx.doi.org/10.1016/S0277-9536(00)00230-6

Beebe-Dimmer, J., Lynch, J.W., Turrell, G., Lustgarten, S., Raghunathan, T., \&

Kaplan, G.A. (2004). Childhood and adult socioeconomic conditions and 31-year mortality risk in women. American Journal of Epidemiology, 159, 481-490.

Bird, C.E. \& Rieker, P.P. (2008). Gender and health: The effects of constrained choices and social policies. New York: Cambridge University Press. http://dx.doi.org/10.1093/aje/kwh057

Borucka, J. (2013). Extensions of Cox Model for non-proportional hazards purpose. Retrieved from http://www.phusewiki.org/docs/Conference\%202013\%20SP\%20Papers/SP07.pdf

Bowen, M.E. (2010). Coronary heart disease from a life-course approach: findings from the Health and Retirement Study, 1998-2004. Journal of Aging and Health, 22, 219. http://dx.doi.org/10.1177/0898264309355981

Brown, T. H., O'Rand, A. M., \& Adkins, D. E. (2012). Race-ethnicity and health trajectories: Tests of three hypotheses across multiple groups and health outcomes. Journal of Health and Social Behavior, 53(3), 359-377. http://dx.doi.org/10.1177/0022146512455333

Centers for Disease Control and Prevention. (2014). Arthritis. Retrieved from http://www.cdc.gov/arthritis/

Coltrane, S. (2000). Research on household labor: Modeling and measuring the social embeddedness of routine family work. Journal of Marriage and the Family, 62, 1208-1233. http://dx.doi.org/10.1111/j.17413737.2000.01208.x 
Corna, L. (2013). A life course perspective on socioeconomic inequalities in health: A critical review of conceptual frameworks. Advances in Life Course Research, 18(2), 150-159. http://dx.doi.org/10.1016/j.alcr.2013.01.002

Crimmins, E.M., Kim, J.K., Sole-Auro, A. (2010). Gender differences in health: results from SHARE, ELSA and HRS. European Journal of Public Health, 22, 81-91.

Danese, A., Pariante, C. M., Caspi, A., Taylor, A., \& Poulton, R. (2007). Childhood maltreatment predicts adult inflammation in a life-course study. Proceedings of the National Academy of Sciences, 104(4), 13191324. http://dx.doi.org/10.1073/pnas.0610362104

DeBoo, H.A., \& Harding, J.E. (2006). The developmental origins of adult disease (Barker) hypothesis. The Australian \& New Zealand Journal of Obstetrics \& Gynaecology, 46, 4-14. http://dx.doi.org/10.1111/j.1479-828X.2006.00506.x

Denton, M., Prus, S., \& Walters, V. (2004). Gender differences in health: A Canadian study of the psychosocial, structural and behavioral determinants of health. Social Science \& Medicine, 58(12), 2585-600. http://dx.doi.org/10.1016/j.socscimed.2003.09.008

deVries, B., \& Watt, D. (1996). A lifetime of events: age and gender variations in thelife story. International Journal of Aging and Human Development, 42(2), 81-102. http://dx.doi.org/10.2190/FM22-V5VT-B60Y$\underline{6 U G C}$

Diprete, T. A., \& Eirich, G. M. (2006). Cumulative advantage as a mechanism for

inequality: A review of theoretical and empirical developments. Annual Review of Sociology, 32, 271-297. http://dx.doi.org/10.1146/annurev.soc.32.061604.123127

Doumas, M., Papademetriou, V., Faselis, C., \& Kokkinos, P. (2013). Gender differences in hypertension: Myths and reality. Current Hypertension Reports, 15, 321-330. http://dx.doi.org/10.1007/s11906-013-0359-y

Drakopoulos, S.A., Lakioti, E., Thedossiou, I. (2011). Childhood socioeconomic deprivation and later adult health. International Journal of Social Economics, 28, 23-38. http://dx.doi.org/10.1108/03068291111091945

Dubay, L.C. \& Lebrun, L.A. (2012). Health, behavior, and health care disparities: Disentangling the effects of income and race in the United States. International Journal of Health Services, 42(4), 607-625. http://dx.doi.org/10.2190/HS.42.4.c

Dupre, M. E. (2007). Educational differences in age-related patterns of disease: Reconsidering the cumulative disadvantage and age-as-leveler. Journal of Health and Social Behavior, 48(1), 1-15. 241. doi: http://dx.doi.org/10.1177/002214650704800101

Elder, G.D, Johnson, M.K., \& Crosnoe, R. (2003). The emergence and development of life course theory. In J.T Mortimer \& M.J. Shanahan (Eds.), Handbook of the Life Course (pp.3-19). New York: Kluwer Academic/Plenum Publishers. http://dx.doi.org/10.1007/978-0-306-48247-2_1

Evans-Campbell, T., Lincoln, K.D., \& Takeuchi, D.T. (2010). Race and mental health: Past debates, new opportunities. In W.R. Avison, J.D. McLeod, \& B.A. Pescosolido (Eds). Mental Health, Social Mirror, (pp.169-190). New York: Springer.

Fitzgerald, J. (2011). Attrition in models of intergenerational links in health and economic status in the PSID. The B.E. Journal of Economic Analysis \& Policy, 11(3), 1-61. http://dx.doi.org/10.2202/1935-1682.2868

Fitzgerald, J., Gottschalk, P., \& Moffitt, R. (1998). An analysis of sample attrition in panel data: The Michigan Panel Study of Income Dynamics. The Journal of Human Resources, 33(2), 251299. http://dx.doi.org/10.2307/146433

Fothergill, K. E., Ensminger, M. E., Green, K. M., Robertson, J. A., \& Juon, H. S. (2009). Pathways to adult marijuana and cocaine use: A prospective study of African Americans. Journal of Health \& Social Behavior, 50(1), 65-81. http://dx.doi.org/10.1177/002214650905000105

Fuller, S., \& Vosko, L.F. (2008). Temporary employment and social inequality in Canada: Exploring intersections of gender, race, and migration. Social Indicators Research, 88(1), 31-50. http://dx.doi.org/10.1007/s11205-007-9201-8 
Galobardes, B., Lynch, J. W., \& Davey Smith, G. (2004). Childhood socioeconomic circumstances and causespecific mortality in adulthood: Systematic review and interpretation. Epidemiologic Reviews, 26, 7-21. http://dx.doi.org/10.1093/epirev/mxh008

George, L.K. (2005). Socioeconomic status and health across the life course: Progress and prospects. Journal of Gerontology, 60B, 135-39. http://dx.doi.org/10.1093/geronb/60.Special_Issue_2.S135

Gilman, S. E., Kawachi, I., Fitzmaurice, G. M., \& Buka, S. L. (2002). Socioeconomic status in childhood and the lifetime risk of major depression. International Journal of Epidemiology, 31(2), 359-367. http://dx.doi.org/10.1093/ije/31.2.359

Gluckman P., \& Hanson M. (2005). The fetal matrix: Evolution, development and disease. Cambridge, UK: Cambridge University Press.

Gustafsson, P. E., \& Hammarström, A. (2012). Socioeconomic disadvantage in adolescent women and metabolic syndrome in mid-adulthood: An examination of pathways of embodiment in the Northern Swedish Cohort. Social Science \& Medicine, 74(10), 1630-8. http://dx.doi.org/10.1016/j.socscimed.2012.01.044

Hamil-Luker, J., \& O'Rand, A. M. (2007). Gender differences in the link between childhood socioeconomic conditions and heart attack in adulthood. Demography, 44(1), 137-158. http://dx.doi.org/10.1353/dem.2007.0004

Halliday, T. J., Kimmitt, M. C., \& Kimmitt, C. (2012). Selective migration and health in the USA. Population Studies, 62(3), 321-334. http://dx.doi.org/10.1080/00324720802339806

Hallqvist, J., Lynch, J., Bartley, M., Lang, T., \& Blane, D. (2004). Can we disentangle life course processes of accumulation, critical period and social mobility? An analysis of disadvantaged socio-economic positions and myocardial infarction in the Stockholm Heart Epidemiology Program. Social Science and Medicine, 58(8), 1555-1562. http://dx.doi.org/10.1016/S0277-9536(03)00344-7

Hannan, C. (2009). Women, gender equality, and diabetes. International Journal of Gynecology and Obstetrics, 104, S4-S7. http://dx.doi.org/10.1016/j.ijgo.2008.11.021

Hayward, M.D, \& Gorman, B.K. 2004. The long arm of childhood: The influences of early life social conditions on men's mortality. Demography, 41(1), 87-107. http://dx.doi.org/10.1353/dem.2004.0005

Heron, M.P. (2007). Deaths: leading causes for 2004. National Vital Statistics Report, 56(5),1-95.

Hogan, R., \& Perrucci, C.C. (2007). Black women: Truly disadvantaged in the transition from employment to retirement income. Social Science Research, 36, 1184-1199. http://dx.doi.org/10.1016/j.ssresearch.2006.07.002

Hunt, K. \& Annandale, E. (1999). Relocating gender and morbidity: Examining men's and women's health in contemporary Western societies. Social Science \& Medicine, 48(1),1-5. http://dx.doi.org/10.1016/S0277-9536(98)00284-6

Johnson, R. C., \& Schoeni, R. F. (2011). Early-life origins of adult disease: national longitudinal population-based study of the United States. American Journal of Public Health, 101(12), 2317-24. http://dx.doi.org/10.2105/AJPH.2011.300252

Kagotho, J. (2009) Examining the longitudinal impact of assets and income on immigrant health behaviors. Washington University in St. Louis.

Kivimaki, M., Lawlor, D.A., Davey Smith, G., Keltikangas-Jarvinen, L., Elovainio, M., Vahtera, J., Pulkki-Raback, L., Taittonen, L., Viikari, J.S.A. \& Raitakari, O.T. (2006). Early socioeconomic position and blood pressure in childhood and adulthood: The cardiovascular risk in young Finns study. Hypertension, 47, 39-44. http://dx.doi.org/10.1161/01.HYP.0000196682.43723.8a

Lemelin, E.T., Diez Roux, A.V, Franklin, T.G., Carnethon, M., Lutsey, P.L., Ni, H. \& Shrager, S. (2009). Life-course socioeconomic positions and subclinical atherosclerosis in the multi-ethnic study of atherosclerosis. Social Science \& Medicine, 68(3), 444-51. http://dx.doi.org/10.1016/j.socscimed.2008.10.038

Lidfeldt, J., Li, T.Y., Hu, F.B., Manson, J.E., \& Kawachi, I. (2007). A prospective study of childhood and adult socioeconomic status and incidence of Type 2 Diabetes in women. American Journal of Epidemiology, 165(8), 882-889. doi: 10.1093/aje/kwk078 
Lipowicz, A., Kozieł, S., Hulanicka, B., \& Kowalisko, A. (2007). Socioeconomic status during childhood and health status in adulthood: the Wrocław growth study. Journal of Biosocial Science, 39(4), 481-91. http://dx.doi.org/10.1017/S0021932006001799

Luo, Y. \& Waite, L.J. (2005). The impact of childhood and adulthood SES on physical, mental, and cognitive wellbeing in later life. Journals of Gerontology Series B: Psychological Sciences and Social Sciences, 60(2),S93S101. doi: 10.1093/geronb/60.2.S93.

Lundberg, U. (1996). The influence of paid and unpaid work on psychophysiological stress responses of men and women. Journal of Occupational Health Psychology, 1, 117-130. http://dx.doi.org/10.1037/10768998.1.2.117

Lundbergy, U. \& Parr, D. (2000). Neurohormonal factors, stress, health, and gender. In R.M. Eisler and M. Hersen (Eds.), Handbook of Gender, Culture, and Health (pp. 21-42). Mahwah, NJ: Lawrence Erlbaum Associates.

Lynch, S. M. (2003). Cohort and life-course patterns in the relationship between education and health: A hierarchical approach. Demography, 40(2), 309-331. http://dx.doi.org/10.1353/dem.2003.0016

Lynch, S.M. (Ed). (2008). Special Issue: Race, Socioeconomic Status, and Health in Life-Course Perspective. Research on Aging, 30(2).http://dx.doi.org/10.1177/0164027507312086

Maty, S.C., Lynch, J.W., Raghunathan, T..E., \& Kaplan, G.A. (2008). Childhood socioeconomic position, gender, adult body mass index, and incidence of Type 2 diabetes mellitus over 34 years in the Alameda County Study. American Journal of Public Health, 98, 1486-1494. http://dx.doi.org/10.2105/AJPH.2007.123653

McDonough, P., \& Berglund, P. (2003). Histories of poverty and selfrated health trajectories. Journal of Health and Social Behavior, 44(2), 198-214. http://dx.doi.org/10.2307/1519808

McDonough, P., Sacker, A., \& Wiggins, R. D. (2005). Time on my side? Life course trajectories of poverty and health. Social Science \& Medicine, 61(8), 1795-1808. http://dx.doi.org/10.1016/j.socscimed.2005.03.021

McGonagle, K.A., Schoeni, R.F., Sastry, N., \& Freedman, V.A. (2013). The Panel Study of Income Dynamics: Overview, Recent Innovations, and Potential for Life Course Research. Longitudinal and Life Course Studies, 3(2), 2-21.

Mckenzie, S.K., Carter, K.N., Blakely, T. \& Ivoery, V. (2011). Effects of childhood socioeconomic position on subjective health and health behaviours in adulthood: how much is mediated by adult socioeconomic position? BMC Public Health, 11, 269. http://dx.doi.org/10.1186/1471-2458-11-269

Meer, J., Miller, D. L., \& Rosen, H. S. (2003). Exploring the health-wealth nexus. Journal of Health Economics, 22(5), 713-730. http://dx.doi.org/10.1016/S0167-6296(03)00059-6

Mensah, F.K. \& Hobcraft, J. (2008). Childhood deprivation, health and development: associations with adult health in the 1958 and 1970 British prospective birth cohort studies. Journal of Epidemiology \& Community Health, 62, 599-606. http://dx.doi.org/10.1136/jech.2007.065706

Miech, R.A., \& Shanahan, M.J. (2000). Socioeconomic status and depression over the life course. Journal of Health and Social Behavior, 41(2), 162-176. http://dx.doi.org/10.2307/2676303

Miller, G.E., Chen, E., \& Parker, K.J. (2011). Psychological stress in childhood and susceptibility to the chronic diseases of aging: Moving toward a model of behavioral and biological mechanisms. Psychological Bulletin, 137, 959-997. http://dx.doi.org/10.1037/a0024768

Moen, P., Robison, J., \& Fields, V. (1994). Women's work and caregiving roles: A life course approach. Journal of Gerontology, 49(4), S176-S186. http://dx.doi.org/10.1093/geronj/49.4.S176

Montez, J.K. \& Hayward, M.D. (2014). Cumulative childhood adversity, educational attainment, and active life expectancy among U.S. adults. Demography, 51, 413-435. http://dx.doi.org/10.1007/s13524-013-0261-x

Murray E.T., Mishra, G.D., Kuh, D., Guralnik, J., Black, S. \& Hardy, R. (2011). Life course models of socioeconomic position and cardiovascular risk factors: 1946 birth cohort. Annals of Epidemiology, 21, 589-597.

http://dx.doi.org/10.1016/j.annepidem.2011.04.005

National Poverty Center. (2013). Poverty in the United States. Ann Arbour, MI: The University of Michigan.

National Center for Health Statistics. (2009). Health, United States, 2008, with chartbook. Hyatsville, MD: Author. 
O'Rand, A. M. (1996). The precious and the precocious: understanding cumulative disadvantage and cumulative advantage over the life course. The Gerontologist, 36(2), 230-8.

http://dx.doi.org/10.1093/geront/36.2.230

Panel Study of Income Dynamics. (2013). Public use dataset. Produced and distributed by the Survey Research Center, Institute for Social Research, University of Michigan, Ann Arbor, MI.

Petrea, R.E., Beiser, A.S., Seshadri, S., Kelly-Hayes, M., Kase, C.S., \& Wolf, P.A. (2009). Gender differences in stroke incidence and poststroke disability in the Framingham Heart Study. Stroke, 40, 1032-1037. http://dx.doi.org/10.1161/STROKEAHA.108.542894

Phillips, J.A. \& Sweeney, M.M. (2005). Premarital cohabitation and marital disruption among white, black, and Mexican American women. Journal of Marriage and Family, 67(2), 296-314. doi: 10.1111/j.00222445.2005.00117.x

Prokos, A.H., Padavic, I., \& Schmidt, A. (2009). Nonstandard work arrangements among women and men scientists and engineers. Sex Roles, 61, 653-665. http://dx.doi.org/10.1007/s11199-009-9680-y

Pudrovska, T., \& Anishkin, A. (2013). Early-life socioeconomic status and physical activity in later life: evidence from structural equation models. Journal of Aging and Health, 25(3), 383-404. http://dx.doi.org/10.1177/0898264312468601

Pudrovksa, T. \& Anikputa, B. (2013). Early-life socioeconomic status and mortality in later life: An integration of four life-course mechanisms. Journals of Gerontology. Series B: Psychological Sciences and Social Sciences, 69(3), 451-460.

Read, J.G. \& Gorman, B.K. (2010). Gender and health inequality. Annual Review of Sociology, 36, 371-386. http://dx.doi.org/10.1146/annurev.soc.012809.102535

Schafer, Markus H, \& Ferraro, K. F. (2012). Childhood misfortune as a threat to successful aging: avoiding disease. The Gerontologist, 52(1), 111-20. http://dx.doi.org/10.1093/geront/gnr071

Sen, G. \& Ostlin, P. (2007). Gender inequity in health: Why it exists and how we can change it. World Health Organization.

Shuey, K. M., \& Willson, A. E. (2008). Cumulative disadvantage and blackwhite disparities in life-course health trajectories. Research on Aging, 30(2), 200-225. http://dx.doi.org/10.1177/0164027507311151

Shuey, K.M. \& Willson, A.E. (2014). Economic hardship in childhood and adult health trajectories: An alternative approach to investigating life-course processes. Advances in Life Course Research, 22, 49-61. http://dx.doi.org/10.1016/j.alcr.2014.05.001

Taylor,S.E., Klein, L.C., Lewis, B.P., Gruenewald, T.L., Gurung, R.A.R. \& Updegraff, J.A. (2000). Biobehavioral responses to stress in females: Tend-and-befriend, not fight-or-flight. Psychological Review, 107, 411429. http://dx.doi.org/10.1037/0033-295X.107.3.411

Turner, R.J. \& Avison, W.R. (2003). Status variations in stress exposure: Implications for the interpretation of research on race, socioeconomic status, and gender. Journal of Health and Social Behavior, 44, 488-505. http://dx.doi.org/10.2307/1519795

Turner, R.J., Wheaton, B., \& Lloyd, D.A. (1995). The epidemiology of social stress. American Sociological Review, 60, 104-125. http://dx.doi.org/10.2307/2096348

Wagmiller, R. L., Lennon, M. C., Kuang, L., Alberti, P. M., \& Aber, J. L. (2006). The dynamics of economic disadvantage and children's life chances. American Sociological Review, 71(5), 847-866. http://dx.doi.org/10.1177/000312240607100507

Walsemann, K. M., Ailshire, J. a, Bell, B. a, \& Frongillo, E. A. (2012). Body mass index trajectories from adolescence to midlife: differential effects of parental and respondent education by race/ethnicity and gender. Ethnicity \& Health, 17(4), 337-62. http://dx.doi.org/10.1080/13557858.2011.635374

Western, B., Bloome, D., Sosnaud, B., \& Tach, L. (2012). Economic insecurity and social stratification. Annual Review of Sociology, 38, 341-359. http://dx.doi.org/10.1146/annurev-soc-071811-145434 
Willson, A. E., Shuey, K. M., \& Elder, G. H., Jr. (2007). Cumulative advantage processes as mechanisms of inequality in life course health. American Journal of Sociology, 112(6), 1886-1924. http://dx.doi.org/10.1086/512712

Zunzunegui, M.-V., Alvarado, B.-E., Béland, F., \& Vissandjee, B. (2008). Explaining health differences between men and women in later life: a cross-city comparison in Latin America and the Caribbean. Social Science \& Medicine, 68(2), 235-42. http://dx.doi.org/10.1016/j.socscimed.2008.10.031

\section{Endnotes}

i Consistent with previous literature using the PSID, $125 \%$ of the US poverty threshold was used because the PSID consistently finds higher reported incomes than the Census Bureau (Wagmiller et al., 2006). 